\title{
ENERGY PRICE SHOCKS AND REGIONAL OUTPUT AND EMPLOYMENT
}

\author{
Douglas R. Bohi and John R. Powers*
}

\begin{abstract}
This paper assesses the importance of energy price shocks to short-term fluctuations in state output and employment. In one set of cross-state regressions, the positive effects of energy production are compared with the negative effects of energy used in industrial production during the 1978-80 period of rising energy prices and the 1985-87 period of falling energy prices. A separate regression compares the effect of energy prices and macroeconomic stabilization policy on economic performance in energy-producing and nonproducing states. Overall, monetary policy appears to be more important than energy prices in explaining relative state economic performance.
\end{abstract}

\section{INTRODUCTION}

Changes in energy prices are often presumed to have well-defined effects on different regions of the country depending on whether the region is a net exporter or a net importer of energy (Miemyk 1978). In particular, it is usually presumed that the economies of energy-producing states benefitted from the major oil price shocks of 1973-74 and 1979-80 and suffered from the dramatic price decrease that occurred at the beginning of 1986, while the rest of the country had the opposite experiences. One need only point to the boom and bust conditions in the oil and gas sectors to illustrate their contribution to overall economic performance in energy-producing states. That the interests of the energy-producing regions seem to run counter to those of the rest of the nation is thought to be reflected in the major recessions experienced after both oil price shocks in the 1970 s and again in 1990 after the Iraqi invasion of Kuwait. ${ }^{1}$

The difference in economic interests between energy-producing and nonproducing states also surfaces in energy policy debates, with the two groups frequently lining up on different sides of the issues. Policies that will raise the revenues of energy producers are often opposed on the grounds that they will transfer income from the residents of energy-consuming states to the residents of energy-producing states. Conversely, representatives from energy-producing states argue for price supports during periods of low energy prices to compensate their constituents for the drain of local resources that go to benefit consumers. The recent debate over President Clinton's energy tax proposals raises similar ques-

\footnotetext{
* Senior Fellow and Director, Energy and Natural Resources Division, Resources for the Future, Washington, D.C., and Graduate Student, Indiana University, Bloomington, Indiana, respectively.
} 
tions about the distribution of the burden of the tax, with energy-producing states generally opposed because of the heavier burden generally felt by industries in those states.

However, energy price changes can affect regional economies in different ways, notwithstanding their comparative positions as importers or exporters of energy. Since energy is used in the production of other goods and services, a change in energy prices will alter the preferred combination of inputs in production and, as energy costs are passed through to consumer prices, the mix of commodities in final demand. Regions will differ in the relative importance of energy as a factor of production, in their ability to adjust to a change in relative factor costs, and in the responsiveness of demand for regional exports due to a change in relative product prices. These separate influences can offset or reinforce the direct price effects associated with being a net exporter or net importer of energy. On balance, oil-exporting regions need not always gain from energy price increases, and oil-importing regions need not always lose.

A good illustration of the assertion that winners and losers cannot be judged solely on the basis of their net import positions occurred after the 1979-80 oil price shock. Although most industrial countries suffered recessions, Britain suffered a deeper recession than most, even though it was an exporter of oil, while Japan avoided a recession altogether, even though it is completely dependent on imports for its energy requirements. ${ }^{2}$

The comparative experiences of different countries after previous oil price shocks is important for another reason. The poor economic performance of most industrial countries after the two oil price shocks of the 1970s may have been more the result of deflationary monetary policy than of the increases in oil prices. ${ }^{3}$ In 1979, Japan consciously sought to avoid a repetition of the bitter experience of 1974, when most major industrial countries tightened their money supplies to fight inflation. Japan alone implemented a more expansionary monetary policy in 1979-80, and Japan alone avoided a recession.

The view that something other than energy prices was responsible for the recessions of the 1970s is suggested by the analysis of sectoral data in Germany, Japan, the United Kingdom, and the United States by Bohi $(1989,1991)$. The analysis fails to find any evidence of a systematic relationship between various activity variables and energy intensity by manufacturing sector, contrary to what one would expect if energy prices were to blame for the downturn. Moreover, there is very little similarity in the way the two recessions in the 1970s affected the various sectors in the four countries, in contrast to what one would expect if the recessions had a common cause.

These observations suggest that it is not obvious which states within the United States will be the winners and losers as a result of fluctuations in energy 
prices. While the energy-producing areas will experience a direct gain from an increase in energy prices, other sectors of the regional economy may lose, and the net outcome can be positive or negative. Hunt (1987), for example, observes that the oil-producing states of Colorado, Oklahoma, and Wyoming responded quite differently to past oil price fluctuations, depending on the extent of diversification of the state economy.

For the United States as a whole, it may be said that the direct loss of GNP due to higher oil prices will be small because of the small cost share of energy in GNP (Denison 1979, 1984). For individual energy-producing states, however, the contribution of energy to GNP can be much more important and could possibly dominate overall economic performance. ${ }^{4}$ Such appears to be the case for Houston and Texas, as indicated in studies by Gilmer (1990) and Gruben and Phillips (1989), who measure the sensitivity of local economic activity to changes in oil prices. Nevertheless, energy-using industries in the major oil-producing states can be affected differently than the energy-producing sectors and moderate the effects of changes in energy prices. For example, the petroleum refining and petrochemical industries tend to benefit from lower crude oil prices and are harmed by higher crude oil prices.

Energy-importing states, in contrast, will experience a direct loss from an increase in energy prices in the form of wealth transfers out of the state as well as positive or negative indirect effects that result from dislocations in non-energy sectors and induced changes in net exports of state products. Miernyk (1978) notes that the energy-importing states must lose what the exporting states gain, but he calculates the gains and losses strictly on the basis of income and employment arising from the energy-producing sector alone. The indirect effects on nonenergy sectors could outweigh the direct effects, so that on balance some importing states could fare better than some exporting states. In particular, states with less energy-intensive industries may experience small dislocation effects and an increase in aggregate export demand. A more recent paper by Brown and Hill (1988) addresses this issue by decomposing the source of employment in each state into that associated with energy production and that associated with all other industry. Unfortunately, the statistical analysis assumes that the non-energy sectors in each state economy will respond to oil prices in the same way as an aggregate national relationship, so that the possible distinctions among states do not show up.

The aim of this paper is to further examine the importance of energy price shocks on state-level economic activity by examining the relative behavior of state output and employment during periods when major energy price shocks occurred. While many factors serve to influence state output and employment, particularly over longer periods of time, our focus is on the importance of energy 
prices on short-term cyclical behavior. In particular, we are concerned with the opposing supply-side effects of changes in energy prices that operate through energy production versus energy consumption, and the relative importance of energy prices versus macroeconomic stabilization policy as alternative explanations of short-term cyclical behavior.

Two separate sets of relationships are examined that attempt to address these issues. The first set of cross-section relationships focuses on the relative importance of energy production and on energy used in production of other goods as two competing explanations of the relative economic performance of states during two important energy price shock periods: $1978-80$ and 1985-87. The first period saw major increases in oil and other energy prices, while the second period witnessed a major collapse of first oil and then other energy prices. We expect that the two hypotheses would exert opposite influences on regional economic activity in each of the periods and that, moreover, both influences would reverse directions between periods of rising and periods of falling energy prices.

To address the question of the relative importance of energy prices and macroeconomic stabilization policy, the second set of pooled time series and crossstate relationships involves estimates of St. Louis-type equations for state output and employment using measures of monetary policy, fiscal policy, and crude oil prices as regressors. ${ }^{5}$ These relationships are also useful for comparing the behavior of the energy-producing states with the nonproducing states. As explained below, the same comparison is not possible with the first set of cross-section relationships.

\section{THE IMPORTANCE OF ENERGY PRODUCTION VERSUS ENERGY USED IN PRODUCTION}

The first set of tests is intended to examine the relative effect of two opposing influences on regional economic activity: the share of energy production in gross state product and the share of energy used to produce other goods and services. States in which a larger share of total production is engaged in energy production will enjoy a larger boost from an increase in energy prices and suffer a larger contraction from a decline in energy prices, compared to states in which energy production is nonexistent or a minor component of total production. ${ }^{6}$ At the same time, states that use relatively more energy in the production of other goods and services will tend to suffer more when energy prices rise, and benefit more when energy prices fall, than states that use energy less intensively in producing other goods and services. 
The first assertion is obvious, but the second deserves elaboration. One part of the expected effect of a change in energy prices is a change in the mix of final demand due to cost-induced changes in relative commodity prices. For example, higher energy prices will tend to raise prices for energy-intensive commodities more than less energy intensive goods and, with normal demand elasticities, will lead to a shift in final demand toward less energy-intensive goods. ${ }^{7}$ Consequently, exports of states that use energy more intensively in production may be expected to suffer relative to other states when energy prices rise and to benefit relative to other states when energy prices fall.

Another implication of changes in energy prices arises because of possible dislocations in non-energy factor markets. For example, an increase in energy prices will tend to cause a reduction in the use of energy as a factor of production, which in turn will tend to reduce the productivity of labor because labor and energy are short-term complements in production (Bruno and Sachs 1985). The reduction in labor productivity implies an increase in labor costs, which will induce employers to respond by either lowering wages or reducing employment. When institutional impediments serve to make wages rigid in the short run, employers will tend to reduce employment, and production will suffer an additional indirect setback. $^{8}$ Again, states that use energy more intensively in production will suffer relative to less energy-intensive states.

States with little or no energy production will be affected only by the dislocations in non-energy sectors caused by changes in energy prices. Energy-producing states, on the other hand, will experience both positive and negative effects. They will experience the same kind of dislocation effects as non-energy states, though perhaps even more strongly than the non-energy states because energy-intensive industries tend to be located in energy-producing states. For example, petroleum refining and petrochemical industries are among the most energy-intensive sectors and are often located in oil- and gas-producing states. Combined with the effects of energy production on overall economic activity, the strongest positive and negative effects of energy price changes could be felt by the same group of states.

To test the relative importance of energy production and energy used in production in each state, we combine measures of both variables in regressions on characteristics of state economic activity. As a measure of the importance of energy production, we use the ratio of mining employment to total state employment in each state. Mining employment is used because more direct measures of the contribution of energy production, such as the ratio of value added in energy production relative to gross state product, or even employment in energy industries alone, are not available in most states. Except for five states where mining employment appears to measure primarily employment in non-energy-extractive industries, this variable is a fairly good proxy for employment in coal, oil, 
and gas extraction. ${ }^{9}$ The five states were nevertheless retained in the sample because comparative regressions revealed that their exclusion does not alter the results.

As a measure of the importance of energy used in state production, we use the ratio of Industrial Energy Consumption (in Btu's) to Gross State Product (measured in constant 1982 dollars). Industrial energy consumption is the closest measure of the amount of energy used in the production of other goods and services that is available. ${ }^{10}$ Two variables are used to characterize state economic activity-gross state product and total state employment-and both are measured as annual percentage changes over the two energy price shock periods: $1978-80$ and 1985-87. ${ }^{11}$

Thus, the regressions have the form

$$
X_{i t}=a+b(M E / T S E)_{i t}+c(I E C / G S P)_{i t}+e_{i t}
$$

for each state $\mathrm{i}$ and energy price shock period $\mathrm{t}$, where $\mathrm{X}$ is either gross state product or total state employment during each period t, ME/TSE is the ratio of mining employment to total state employment at the beginning of period $t$, and IEC/GSP is the ratio of industrial energy consumption to gross state product in the beginning of each period $t$. Three cross-state regressions are run for the 1978-80 and 1985-87 energy price shock periods. We expect that $b>0$ and $c<0$ when energy prices are rising and the opposite signs when energy prices are falling. Because the parameters change sign from periods of rising to falling energy prices, pooling the time periods would combine these opposite influences and possibly not yield meaningful coefficients. The inability to pool states across time periods also means that there are insufficient degrees of freedom to split the sample between energy-producing and nonproducing states. There are only 12 significant energy-producing states (see Table 3 for a list of these states) and thus only 12 observations for this group in each time period.

The estimates for gross state product are reported in Table 1, and the estimates for total state employment are given in Table 2. Both tables give the same general picture. The coefficients of both energy intensity variables are significant in the 1978-80 and 1985-87 time periods, but only the coefficient of the ME/TSE variable has the expected sign in both periods. Energy production contributed positively to total output and employment when energy prices rose in 1978-80 and contributed negatively to output and employment when energy prices fell in 198587. The industrial energy consumption variable, on the other hand, has a negative sign (as expected) in 1978-80 but also a negative sign (contrary to expectations) in 1985-87. One might be tempted to interpret the result for 1985-87 to mean that any price shock, even though it may be a decline in energy prices, has negative 
TABLE 1

Gross State Product ${ }^{\mathrm{a}}$

(Standard Errors in Parentheses)

\begin{tabular}{lcc}
\hline \hline & \multicolumn{2}{c}{ Energy Price Shock Period } \\
\cline { 2 - 3 } Independent & & \\
Variable & $1978-80$ & $1985-87$ \\
\hline Constant & .051 & .061 \\
& $(.049)$ & $(.019)$ \\
ME/TSE & 1.443 & -1.265 \\
& $(.313)$ & $(.217)$ \\
IEC/GSP & -3.772 & -2.365 \\
& $(1.339)$ & $(.686)$ \\
$\mathrm{R}^{2}$ & .314 & .716 \\
$\mathrm{n}$ & 50 & 50 \\
$\mathrm{D}-\mathrm{W}$ & 1.76 & 2.05 \\
\hline
\end{tabular}

${ }^{2}$ Measured in annual percentage changes.

TABLE 2

Total State Employment ${ }^{\mathrm{a}}$

(Standard Errors in Parentheses)

\begin{tabular}{lcc}
\hline \hline & \multicolumn{2}{c}{ Energy Price Shock Period } \\
\cline { 2 - 3 } Independent & $1978-80$ & $1985-87$ \\
\hline Variable & .049 & .069 \\
Constant & $(.037)$ & $(.026)$ \\
& .679 & -1.083 \\
ME/TSE & $(.238)$ & $(.295)$ \\
& -1.945 & -1.922 \\
IEC/GSP & $(1.018)$ & $(.935)$ \\
& .151 & .490 \\
$\mathrm{R}^{2}$ & 50 & 50 \\
$\mathrm{n}$ & 1.67 & 2.12 \\
$\mathrm{D}-\mathrm{W}$ & &
\end{tabular}

${ }^{\mathrm{a}}$ Measured in annual percentage changes. 
implications for output and employment. This view has some currency among those who attempt to explain the absence of an economic boom at the national level after 1986, either in the United States or in other industrial countries. ${ }^{12}$ However, it is difficult to come up with a convincing story that will explain this outcome. When energy prices fall, producers using energy as a factor of production experience a windfall gain and have the luxury of choosing between maintaining the status quo (by not lowering product prices and by not hiring additional labor) or exploiting their cost advantage. In contrast to the situation when energy prices rise, they need not choose an option that makes them worse off, as implied by the negative coefficient for IEC/GSP in 1985-87. The temptation is to regard the very good fit for the 1985-87 regression as the result of spurious correlation, although too little is known about the potential disruptive effects of cost decreases to rule out the possibility of an asymmetric relationship between energy prices and economic activity.

\section{ENERGY PRICES VERSUS STABILIZATION POLICY}

To assess the quantitative significance of oil prices and stabilization policy on gross output in each state, we estimate a reduced form St. Louis- type equation (see Batten and Thornton 1983; Gisser and Goodwin 1986) for each state $(i=1, \ldots, 50)$ that takes the form

$$
X_{i t}=a+b M_{i t}+c F_{i t}+d P O_{i t}+e_{i t}
$$

where $\mathbf{X}$ is gross state product or total state employment, $\mathbf{M}$ is the money supply (M1B), $\mathrm{F}$ is the high employment federal expenditures measure of fiscal policy (Hafer 1982), and PO is the nominal price of crude oil. All variables are measured in annual percentage changes over the period 1972-86. Data sources are shown in the Appendix. The price of oil may be taken as a surrogate for all energy prices, since oil prices tend to drive natural gas and coal prices.

Unlike the previous setup, here we are able to separate the states into groups according to whether or not they are significant energy producers. The monetary and fiscal policy variables are presumed to affect all states in the same direction (i.e., $b>0$ and $c>0$ for all states), while the coefficient of the oil price variable is unambiguous only for the group of non-energy-producing states $(d<0)$. The sign of the coefficient for the energy-producing states can be positive or negative, depending on the relative influence of energy production versus energy used in production on overall economic activity. 
TABLE 3

St. Louis-Type Equations for Gross State Product ${ }^{\mathrm{a}}$ (Standard Errors in Parentheses)

\begin{tabular}{lccc}
\hline \hline $\begin{array}{l}\text { Independent } \\
\text { Variables }\end{array}$ & $\begin{array}{c}\text { Oil-Producing } \\
\text { States }\end{array}$ & $\begin{array}{c}\text { Other Energy- }{ }^{\mathrm{c}} \\
\text { Producing States }\end{array}$ & $\begin{array}{c}\text { Non-Oil }^{\mathrm{d}} \\
\text { States }^{-}\end{array}$ \\
\hline Constant & 4.658 & 14.857 & 13.079 \\
Money supply & $(7.580)$ & $(2.406)$ & $(1.145)$ \\
& .922 & .709 & .343 \\
Fiscal policy & $(.563)$ & $(.179)$ & $(.085)$ \\
& -.531 & .622 & .697 \\
Price of crude oil & $(.377)$ & $(.120)$ & $(.057)$ \\
& .001 & -.007 & -.006 \\
$\mathrm{R}^{2}$ & $(.020)$ & $(.006)$ & $(.003)$ \\
$\mathrm{n}$ & .209 & .248 & .265 \\
$\mathrm{D}-\mathrm{W}$ & 70 & 98 & 630 \\
\hline
\end{tabular}

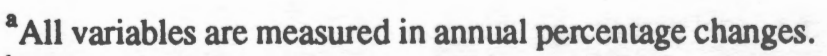

Includes Alaska, Louisiana, Oklahoma, Texas, and Wyoming.

'Includes California, Colorado, Kansas, Kentucky, Mississippi, New Mexico, and West Virginia.

dincludes the 45 states not included in the group of "oil-producing states."

Tables 3 and 4 present the results for gross state product and total state employment, respectively, and for three different groups of states. The first column in each table is based on a pooling of five major oil- and gas-producing states that include Alaska, Louisiana, Oklahoma, Texas, and Wyoming. The second column combines seven other energy-producing states, which are less important oil and gas producers, and the major coal-producing states, which include California, Colorado, Kansas, Kentucky, Mississippi, New Mexico, and West Virginia. The third column includes all 45 states not represented among the major oil- and gas-producing states in the first column. ${ }^{13}$

Again, the results for gross state product and total state employment tell the same story. Monetary policy has had an important deflationary effect on all states during the years of energy price turmoil and in general has been a more important determinant of state economic activity than the price of oil. ${ }^{14}$ It is of interest to note that the coefficient of the price of oil is statistically insignificant for both groups of energy-producing states, while negative and significant for the non-oil 
TABLE 4

St. Louis-Type Equations for Total State Employment ${ }^{a}$ (Standard Errors in Parentheses)

\begin{tabular}{lccc}
\hline \hline $\begin{array}{l}\text { Independent } \\
\text { Variables }\end{array}$ & $\begin{array}{c}\text { Oil-Producing } \\
\text { States }\end{array}$ & $\begin{array}{c}\text { Other Energy- }{ }^{\mathrm{c}} \\
\text { Producing States }^{-}\end{array}$ & $\begin{array}{c}\text { Non-Oil } \\
\text { States }^{\mathrm{d}}\end{array}$ \\
\hline Constant & 10.508 & 12.622 & 10.450 \\
Money supply & $(4.350)$ & $(2.220)$ & $(.897)$ \\
& 1.126 & .649 & .369 \\
Fiscal policy & $(.319)$ & $(.163)$ & $(.066)$ \\
& -.145 & .504 & .511 \\
Price of crude oil & $(.207)$ & $(.106)$ & $(.043)$ \\
& .003 & .005 & -.007 \\
$\mathrm{R}^{2}$ & $(.011)$ & $(.006)$ & $(.002)$ \\
$\mathrm{n}$ & .385 & .196 & .194 \\
$\mathrm{D}-\mathrm{W}$ & 75 & 105 & 675 \\
& 1.16 & 1.04 & 1.02 \\
\hline
\end{tabular}

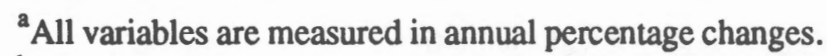

Includes Alaska, Louisiana, Oklahoma, Texas, and Wyoming.

'Includes California, Colorado, Kansas, Kentucky, Mississippi, New Mexico, and West Virginia.

dncludes the 45 states not included in the group of "oil-producing states."

states. The latter result is the expected outcome for nonproducing states, while the former outcome is the apparent net result of the dual opposing influences operating in the energy-producing states. In other words, the inverse effect of the cost of oil in the production of other goods and services comes through clearly in the nonproducing states but is offset by the positive effect of energy production on activity in the producing states. Thus, while it may be true that energy production dominates some regional economies (e.g., Houston and Texas, as indicated earlier), the same cannot be said for all of the energy-producing states. ${ }^{15}$

\section{CONCLUSIONS}

Energy price shocks produce both positive and negative influences that are significant in explaining the comparative short-term economic performance of different regions of the country. Because both influences are present among the 
energy-producing regions, the net effect of changes in energy prices can be positive or negative for any specific region. For the entire group of energy-producing states, the net effect appears to be a wash. Based on these results, one may conclude that the economic interests of the energy-producing states with respect to fluctuations in energy prices are not as divergent from those of the rest of the country as one might expect. A focus on the boom and bust cycle in the oil- and gas-producing sectors, in particular, appears to be a misleading indicator of overall state economic welfare.

While changes in energy prices have played a significant role in regional economic performance, our results do not support the view that energy prices had a dominant influence on either energy-producing or nonproducing states in either the immediate aftermath of the energy price shocks or over the 14 years spanning the major oil price fluctuations. Monetary policy, in particular, appears to be more important in explaining cyclical behavior after the oil price shocks than oil prices. Moreover, in view of the generally low explanatory power of our regressions, excluded variables have played an even more important role than energy prices.

\section{ENDNOTES}

1. However, these recessions may not have been caused by increases in oil prices, as indicated in Bohi $(1989,1991)$. One of several reasons for doubt is that the United States and other industrial countries did not enjoy an economic boom after the price of oil decreased by half in 1986.

2. See Bohi $(1989,1991)$ for analyses of the comparative economic performance of Germany, Japan, the United Kingdom, and the United States during the two oil crises of the 1970s.

3. See Bruno (1986) and Bohi (1989).

4. Branson and Love (1987) find that manufacturing employment is more sensitive to exchange rate movements in states engaged in crude oil production.

5. Gisser and Goodwin (1986) perform a similar analysis of aggregate U.S. data.

6. Energy production refers to primary energy and excludes generation of electricity.

7. Final demand will also shift in favor of goods that are more energy efficient, but we have no way to distinguish among the states in this regard.

8. Analysis of sectoral data for four countries by Bohi (1991) reveals systematic downward pressure on sectoral wages when energy prices have increased but no apparent systematic effect on sectoral output. 
9. The five states are Idaho, Minnesota, Montana, Nevada, and North Dakota.

10. We ignore the possible income effect associated with final consumption of energy-where income transfers out-of-state to pay for energy are not matched by transfers in to pay for exports-because such effects are likely to be small and, in any case, dominated by changes in national stabilization policy. The latter effects are taken up in the next section.

11. Data were available for only 28 states for the 1973-75 energy price shock period, and the regressions were not significant. Consequently, the results for 1973-75 are not reported here.

12. The lack of symmetry between the effects of rising and falling oil prices at the national level has been studied by Mork (1989). One possible explanation for the lack of symmetry is that industrial energy consumption is highly correlated with manufacturing intensiveness, and that the energy consumption variable is capturing the relative performance of service-oriented versus manufacturing states.

13. The results for the group of "non-oil-producing" states were essentially the same as that for the group of "non-energy-producing" states, so the latter results were not reported.

14. This is the same conclusion reached by Bohi (1989) regarding the macroeconomic performance of Germany, Japan, the United Kingdom, and the United States during the same period, as well as a more general observation by Bruno (1986).

15. Sherwood-Call (1988) has studied long-term relationships between national and regional economies and finds that states with larger oil and gas sectors have weaker linkages to the national economy.

\section{APPENDIX: DATA SOURCES}

Gross State Product (constant 1982 dollars): Bureau of Labor Statistics, U.S. Department of Census, 1990.

Total State Employment: Bureau of Labor Statistics, "Annual Average Population, CPS Estimates." U.S. Department of Census, 1990.

Mining Employment: "Employment, Hours, and Earnings: States and Areas, 1972-87." Volumes 1-5, Bulletin 2320, U.S. Department of Labor.

Industrial Energy Consumption by State (Btu's): State Energy Data Report. Energy Information Administration, 1960-88.

Oil Prices: "Crude Oil Imported Refiner Acquisition Cost." Monthly Energy Review, Energy Information Administration, U.S. Department of Energy. 
Money Supply: "Money Stock (M1)." H. 6, Federal Reserve Board, Washington, D.C.

Federal Expenditures: "Cyclically Adjusted Federal Expenditures and Receipts." Government Division, Bureau of Economic Analysis, Bureau of Census, U.S. Department of Commerce.

\section{REFERENCES}

Batten, Dallas S., and Daniel L. Thornton. "Polynominal Distributed Lags and the Estimation of the St. Louis Equation." Federal Reserve Bank of St. Louis Review 65 (1983): 13-25.

Bohi, Douglas R. Energy Price Shocks and Macroeconomic Performance. Washington, D.C.: Resources for the Future, 1989. "On the Macroeconomic Effects of Energy Price Shocks." Resources and Energy 13 (1991): 145-162.

Branson, William H., and James P. Love. "The Real Exchange Rate and Employment in U.S. Manufacturing: State and Regional Results." NBER Working Paper no. 2435, 1987.

Brown, S. P., and J. K. Hill. "Lower Oil Prices and State Employment." Contemporary Policy Issues 6 (1988): 60-68.

Bruno, Michael. "Aggregate Supply and Demand Factors in OECD Unemployment." Economica 53 (1988, Supplement): 535-552.

Bruno, Michael, and J. Sachs. Economics of Worldwide Stagflation. Cambridge, Mass.: Harvard University Press, 1986.

Denison, Edward F. Accounting for Slower Economic Growth. Washington, D.C.: The Brookings Institution, 1979.

"Accounting for Slower Economic Growth: An Update." In International Comparisons of Productivity and Causes of the Slowdown, edited by J. W. Kendrick. Cambridge, Mass.: Ballinger Publishing Co., 1984. Gilmer, Robert W. "Oil Prices and Manufacturing Growth: Their Contribution to Houston's Economic Recovery." Federal Reserve Bank of Dallas Economic Review (1990): 13-22.

Gisser, Micha, and Thomas H. Goodwin. "Crude Oil and the Macroeconomy: Tests of Some Popular Notions." Journal of Money, Credit, and Banking 18 (1986): 95-103.

Gruben, William C., and K. R. Phillips. "Diversifying Texas: Recent History and Prospects." Economic Review (1989): 1-12.

Hafer, R. W. "The Role of Fiscal Policy in the St. Louis Equation:" Federal Reserve Bank of St. Louis Review 64 (1982): 17-22. 
Hunt, Gary L. "The Impact of Oil Price Fluctuations on the Economies of Energy Producing States." The Review of Regional Studies 17 (1987): 60-76.

Miemyk, W. H. "Some Regional Impacts of the Rising Costs of Energy." In Regional Impacts of Rising Energy Prices, edited by W. H. Miernyk, F. Giarratani, and C. F. Socher. Cambridge, Mass.: Ballinger Publishing Co., 1978.

Mork, Knut Anton. "Oil and the Macroeconomy When Prices Go Up and Down." Journal of Political Economy 97 (1989): 740-749.

Sherwood-Call, Carolyn. "Exploring the Relationship Between National and Regional Economic Fluctuations." Federal Reserve Bank of San Francisco Economic Review 3 (1988): 15-25. 